\title{
Alpha-2 Country Code
}

National Cancer Institute

\section{Source}

National Cancer Institute. Alpha-2 Country Code. NCI Thesaurus. Code C54641.

The two-letter country codes specified by the ISO 3166-1 country code standard. 